\title{
Phytoremediation Potential of Fast-Growing Energy Plants: Challenges and Perspectives - a Review
}

\author{
Martin Hauptvogl ${ }^{1 *}$, Marián Kotrla², Martin Prčík ${ }^{1}$, Žaneta Pauková ${ }^{3}$, \\ Marián Kováčik ${ }^{4}$, Tomáš Lošák ${ }^{5}$ \\ ${ }^{1}$ Department of Environmental Management, Slovak University of Agriculture in Nitra, Slovakia \\ ${ }^{2}$ Department of Regional Bioenergetics, Slovak University of Agriculture in Nitra, Slovakia \\ ${ }^{3}$ Department of Regional Bioenergetics, Slovak University of Agriculture in Nitra, Slovakia \\ ${ }^{4}$ Department of EU Policies, Slovak University of Agriculture in Nitra, Slovakia \\ ${ }^{5}$ Department of Environmentalistics and Natural Resources, Mendel University in Brno, Czech Republic
}

Received: 23 July 2018

Accepted: 15 December 2018

\begin{abstract}
Contamination of soil by toxic elements is a global issue of growing importance due to the increased anthropogenic impact on the natural environment. Conventional methods of soil decontamination possess disadvantages in forms of environmental and financial burdens. This fact leads to the search for alternative approaches of remediation of contaminated sites. One such approach includes phytoremediation. Phytoremediation advantages consist of low costs and small environmental impact. Several fast-growing energy plant species are suitable for phytoremediation purposes. Our article focuses on the phytoremediation potential of energy woody crops of Salix and Populus, and energy grasses Miscanthus and Arundo, which are grown primarily for biomass production. This approach links the environmentally friendly and economically less demanding remediation approach with the production of the local sustainable form of energy that decreases dependency on external energy supplies. Energy plants are able to provide high biomass yields in a short period of time, they are resistant against abiotic stress conditions and have the ability to accumulate toxic substances, thus helping to restore the desirable soil properties. The phytoremediation research is very interdisciplinary in its nature. In order to implement phytoremediation practices together with bioenergy successfully, it is crucial to involve site owners, local people, farmers, technology providers and consultants, remediation experts, sustainability assessors, regulatory agencies and certification bodies, biorefineries, financial sponsors, NGOs and other voluntary organizations. Some disadvantages and challenges of phytoremediation are also indicated.
\end{abstract}

Keywords: biomass production, energy plant, environmental contamination, phytoremediation, toxic elements

*e-mail: martin.hauptvog1@uniag.sk 


\section{Introduction}

Risk elements naturally occur in the Earth's lithosphere as well as in soils, waters and living organisms. Many of them represent an essential part of the biological processes, but some of them are toxic to living organisms. A large proportion of heavy metals and metalloids enter the environment by human activities [1-6]. Their excess concentrations are absorbed by living organisms entering the food chain [7-10]. Heavy metals and metalloids pose a serious risk to human health due to their toxic effects [11-14]. Contamination of the environment with heavy metals and metalloids is a serious global problem that has been given increasing attention in recent decades [15] due to the fact that their negative environmental impact is particularly severe [16]. The use of biological material as an indicator for the detection and continual monitoring of the presence of these toxic substances is currently a very topical issue $[17,18]$.

Certain plants and microbes are able to remove contaminants from the environment and store them in their bodies [12, 19, 20]. A list of plant species reported for phytoremediation of toxic elements includes the genera Acer, Arundo, Astragalus, Betula, Brassica, Cannabis, Castor, Eucalyptus, Helianthus, Jatropha, Linum, Miscanthus, Phalaris, Pisum, Populus, Quercus, Ricinus, Robinia, Salix, Sarcocornia, Sorghum, Zea mays and many others [12, 21-30]. Plants used for remediation purposes should be able to grow in less favourable edaphic conditions concerning soil salinity, soil $\mathrm{pH}$, and water content. They should create a dense root system and be resistant to pathogens and diseases [31, 32]. In this way, they can contribute to the biological remediation of contaminated soils and thus improve their properties that are important for ensuring ecosystem services, biodiversity, and food production, as well as human health [33], and restore the balance in a stressed environment [34].

Energy crops are plants grown for their biomass production that can be utilized to make biofuels or combusted to generate heat or electricity. They are also seen as an important component of climate mitigation measures and one of the resources for displacing fossil fuels [35-37]. In addition to the growth characteristics and biomass production of the selected energy crops (Salix, Populus, Miscanthus and Arundo) [38-46], our study focuses on their potential to be used for phytoremediation purposes, i.e., phytostabilization, rhizofiltration and phytoextraction of toxic pollutants - especially heavy metals and metalloids from the soil that are accumulated in their extensive root system and aboveground biomass [47-49].

In the following chapters, the issue of environmental contamination and the phytoremediation abilities of the selected energy plants is discussed.

\section{Results and Discussion}

Human activities do not change the overall composition of metal elements on Earth, but they change their distribution and concentration [50]. Major anthropogenic sources of heavy metal and metalloid contamination include mining and industrial waste, smelting of ores, urban soil waste, sewage sludge, wastewater, fertilizers and pesticides [11, 26, 51]. They are accumulated in the environment and may pose serious toxic effects on human health $[12,52]$.

Pollution by heavy metals and metalloids is caused both by the natural occurrence of ores and anthropogenic activity. Environmental contamination prevails around mines and ore processing areas, agricultural soils, and some industrial and urban centres [53]. The pollutants are introduced mostly in the form of dust particles, by leaching from mining areas and landfills, and also from the overuse of inorganic fertilizers [54].

The monitoring of soil pollution is focused mainly on the following risk elements: $\mathrm{As}, \mathrm{Cd}, \mathrm{Co}, \mathrm{Cr}, \mathrm{Cu}, \mathrm{F}$, $\mathrm{Hg}, \mathrm{Ni}, \mathrm{Pb}$, Se, and $\mathrm{Zn}[55,56]$.

In many places, huge health risk is posed by tailing ponds representing potentially contaminated and/or contaminated sites [57]. They contain mainly wastes from coal and ore processing activities, heating plants and power plants. Due to their high environmental risk as well as expensive maintenance, great attention has been given to their re-cultivation and stabilization [58-60].

Plant species that spontaneously occur in areas affected by mining activities and/or soils degraded and contaminated by other industrial activities include the genera Salix, Populus, Betula, Robinia, Acer and Pyrus. This spontaneous vegetation of native flora provides natural rehabilitation of the contaminated areas by having positive visual impact, preventing the spread of the tailings by air and water. The vegetation is able to withstand high concentrations of contaminants, and many native species have high potential for phytostabilization and phytoextraction of the contaminants $[61,62]$. These abilities enable the native vegetation to decrease overall air, water and soil pollution [63-65]. Goat willow (Salix caprea) is one of the typical pioneer species that can be found at former ore mining sites in Eastern and Middle Europe. Its high tolerance and capacity to absorb and accumulate risk elements points to the possibility of using this native species in remediation of polluted sites [66]. According to Pandey [67], the use of naturally colonizing, economically valuable and perennial plants that are unpalatable to livestock (e.g., Jatropha curcas, Miscanthusgiganteus and Ricinuscommunis) is the best strategy for sustainable phytoremediation of contaminated soils.

Phytoremediation is the use of certain plants to immobilize, extract, degrade and/or accumulate toxic elements, mainly heavy metals and metalloids, from 
the environment (soil, water and air). Phytoremediation can be divided into three subsets applicable to contaminant remediation: phytoextraction, rhizofiltration and phytostabilization. Phytoextraction is the use of plants to remove toxic elements from soils. Rhizofiltration is the use of plant roots to remove toxic elements from polluted waters. Phytostabilization is the use of plants to eliminate the bioavailability of toxic elements in soils [68-71]. Except for toxic metals/metalloids, the bioremediation technologies can be used for remediating soils contaminated with other contaminants such as petroleum hydrocarbons, polycyclic aromatic hydrocarbons, polychlorinated biphenyls, solvents, military munition waste, salt $(\mathrm{NaCl})$ and radioisotopes [24, 72]. Although there is scientific proof that phytoremediation provides a cost-effective tool for in situ remediation of contaminated sites, it is not easy to implement it in practice due to a certain status quo bias and preference of conventional methods by practitioners [73]. Therefore, phytoremediation technology has been mostly in the research stage. The current research is aimed at genetic modification of some plants in order to increase the phytoremediation efficiency of heavy metals and other xenobiotics. Improvement of metal accumulation can lead to the promotion of phytomining - the use of plants for metal mining. Although this environmentally friendly remediation of polluted soils, sediments and water has not been commercialized and used extensively on a large scale, it is expected to become commercially viable technology in the future [11, 31]. Results of a two-year phytoremediation project conducted on soils contaminated with $\mathrm{As}, \mathrm{Cd}$, and $\mathrm{Pb}$ showed that costs were lower than for most other technologies, and the benefits of phytoremediation are expected to offset the project costs in less than seven years [74]. Phytoremediation efficiency and biodegradation of organic contaminants, as well as plant growth, can be enhanced by suitable combinations of plants and their associated endophytes. However, the studies on endophytes are mainly based on laboratory experiments and so far they have rarely been conducted under field conditions $[75,76]$.

Favas et al. [64], Hybská [77], Rungwa et al. [78] and Tangahu et al. [79] summarized the advantages and disadvantages and/or limitations of phytoremediation technologies. The advantages are that they are suitable for various types of contaminants (organic substances, metals and metalloids), the financial costs are low and they do not require energy delivery (energy is obtained from solar radiation). The plant stands are considered environmentally friendly and aesthetically pleasing. They can also contribute to the improvement of the visual aspect of the landscape, provide habitats for animals, reduce dispersal of dust and contaminants by wind and surface runoff, and reduce leaching and mobilization of contaminants in soil. Other environmental benefits include erosion control, minimal site destruction and destabilization, carbon sequestration and improving soil quality and functionality. There is also a socio-economic benefit to providing job opportunities for local labour. Energy plantations established on contaminated lands do not compete with food production. Phytoremediation can be combined with other remediation methods (e.g., soil washing, soil vapour extraction) [80]. The disadvantages of phytoremediation are that the process is slower than normal physicochemical methods, and the decontamination process can be negatively affected by changes in the living conditions of plants (water, nutrients and oxygen) as well as other factors (e.g., structure of the soil profile, $\mathrm{pH}$, salt concentration and presence of other toxins). Contaminants cannot be completely removed by phytoremediation processes and they might enter the food chain if the accumulator plants are ingested by animals. The technology is applicable to moderately contaminated land. It cannot compete with conventional remediation on heavily polluted sites [80]. Another limitation is that phytoremediation techniques are still under development and therefore they are not accepted by many regulatory agencies. Mosa et al. [31] point out that the phytoremediation potential has not been fully exploited. There are not many commercial-scale applications of this technology for cleaning contaminated soil and water. Inadequate funding of phytoremediation research is also a major problem. There is also concern about the content of toxic elements in the biomass of energy crops produced on contaminated land that may generate hazardous emissions [80].

Phytoremediation research is interdisciplinary in its nature. It involves plant biology, ecology, soil chemistry, soil microbiology and environmental engineering [11].

In order to increase the tolerance, uptake and hyperaccumulation of heavy metals and metalloids by plants, it is essential to integrate genetic engineering and "omics" tools, such as genomics, transcriptomics, proteomics, metabolomics and phenomics. These tools could help to identify genes that would enhance the phytoremediation abilities of plants [31, 52]. Involvement of respective stakeholders such as site owners, local people, farmers, technology providers and consultants, remediation experts and sustainability assessors, regulatory agencies and certification bodies, biorefineries and financial sponsors, NGOs and other voluntary organizations is a crucial aspect of coupling bioenergy production with the phytoremediation of polluted lands. They play an important role in the successful establishment of energy plantation and remediation processes. Suitable species should be properly selected and plantation ("biofuel park") models should be developed to ensure economic benefits of the bioremediation activities [81]. In this sense, the involvement of geographical information system (GIS) tools is essential in order to obtain and process data and information on plant suitability and environmental characteristics and conditions [82]. As Montpetit and Lachapelle [73] pointed out, "knowledge is key to the successful implementation of a phytoremediation plan 
on a contaminated site." Besides publishing research results in scientific journals, reaching practitioners on the ground as well as informing and educating public and private sectors is doubly important and should lead to greater acceptance for the application of phytoremediation [24].

Soils contaminated by heavy metals and metalloids represent high environmental and health risks, and such soils are not suitable for food production. Studies confirmed that the ability of plants to decontaminate soils polluted with heavy metals is very different [32, $83,84]$. Therefore, it is important to find specific plants for phytoextraction or phytostabilization of specific toxic elements.

Bioenergy production is a subject of ongoing discussion due to its impact on the environment, food security and overall production potential [85]. Coupling bioenergy production with the phytoremediation of contaminated land and water is a very promising strategy that brings an added environmental value [86, 87]. The advantages of using energy plants (woody crops and grasses) for phytoremediation activities include their ability to provide high biomass yields in a short period of time, and the ability to cope with stress and resistance against abiotic conditions (Fig. 1). Pandey et al. [27] and Tripathi et al. [81] provided a comprehensive list of energy crops suitable for combining their biomass production used for energy purposes with the phytoremediation potential of different pollutants. Mosa et al. [31] pointed out that genomic and metabolic engineering strategies should be developed to improve the tolerance uptake and hyperaccumulation of heavy metals and metalloids. Furthermore, breeding programs should be developed to improve the biomass production and growth habits of natural hyperaccumulators and breed those traits into non-food, high biomass, fast-growing plants for commercial phytoremediation of heavy metals and metalloids.

Short rotation coppice (SRC) plantations of fastgrowing woody crops such as willows (Salix) and poplars (Populus) [88, 89] offer a cost-effective and environmentally friendly method of phytoremediation in various areas. These areas include replacement of small wastewater treatment works, management of industrial and farm wastewater, landfill leachate management and recycling [90-92], remediation of hazardous waste disposal sites [93, 94], heavy metal-contaminated land [95] and groundwater contaminated with pesticides [96]. The method is also applicable for the in-situ treatment of tailing ponds [97].

A number of willow species and varieties tolerate metal contaminants (such as $\mathrm{Cd}, \mathrm{Cu}, \mathrm{Pb}$ and $\mathrm{Zn}$ ) relatively well and are able to accumulate high concentrations of these toxic substances [98-100] and thus help to restore the desirable soil properties. Gommers et al. [101] reported the suitability of the establishment of an SRC willow plantation on radiocaesium-contaminated land. Salix schwerinii showed resistance to soil polluted with $\mathrm{Al}, \mathrm{Cr}, \mathrm{Cu}, \mathrm{Fe}, \mathrm{Ni}, \mathrm{Si}$, and $\mathrm{Zn}$ and potential to uptake excess nutrients into plant organs. Willows are able to accumulate a large percentage of $\mathrm{Cr}$, followed by $\mathrm{Zn}, \mathrm{Cu}$ and Ni [102]. Salix matsudana showed great potential in the remediation of $\mathrm{Pb}$ contaminants [103]. Kacálková et al. [104] and Kubátová et al. [105] reported that willows accumulated higher amounts of $\mathrm{Cd}, \mathrm{Cu}$ and $\mathrm{Zn}$ than poplars, indicating that willows are more suitable for phytoextraction of these elements.

An outdoor short-term pot experiment demonstrated the potential of black poplar (Populus nigra 'Italica') in phytoremediation of $\mathrm{Cd}$ and $\mathrm{Pb}$. The tested poplar could be potentially used for phytoextraction processes of $\mathrm{Cd}$ in moderately contaminated soils, but only for phytostabilization in heavily contaminated soils.

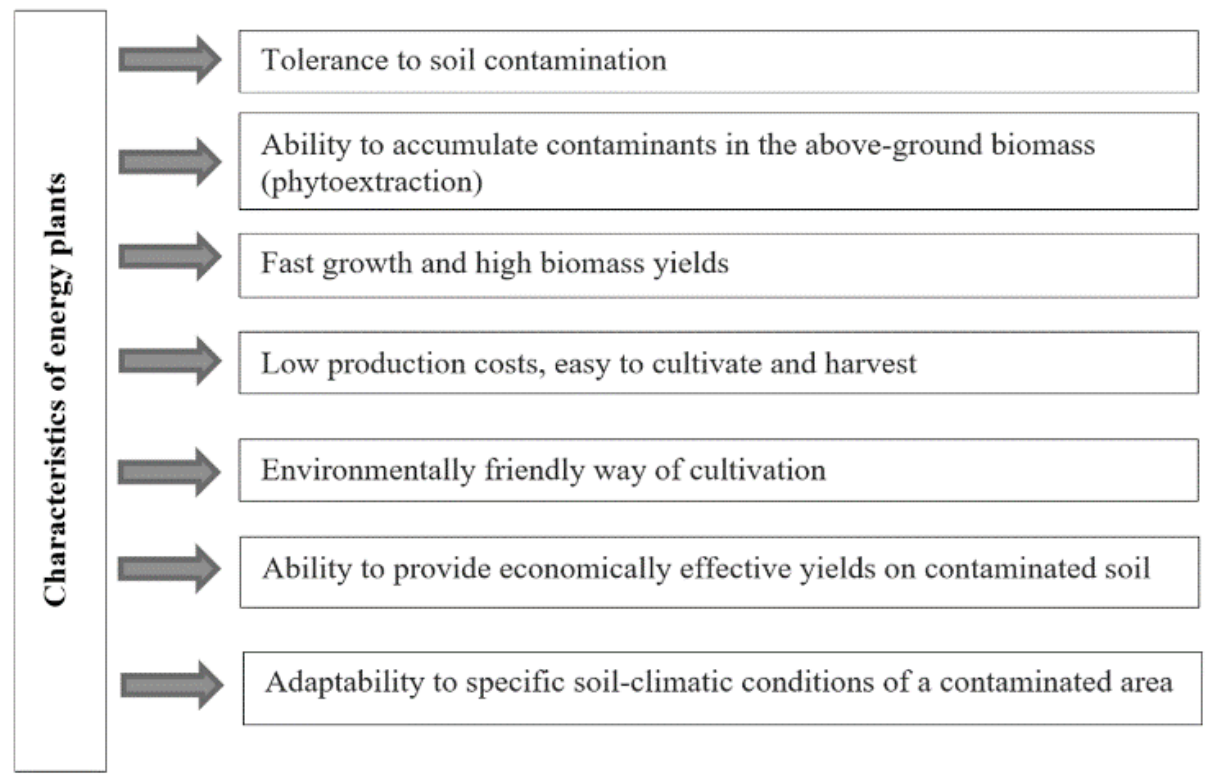

Fig. 1. Characteristics of energy plants required for phytoremediation technologies [81]. 
It can be considered only as a phytostabilizator for $\mathrm{Pb}$ remediation [106].

A study realised in three different sites in Denmark contaminated by $\mathrm{Cd}, \mathrm{Cu}, \mathrm{Ni}, \mathrm{Zn}, \mathrm{Cr}$ and $\mathrm{Pb}$ showed the feasibility of willows and poplars for the phytoextraction of the elements. Willows had higher extraction efficiencies than poplars [93]. Yang et al. [107] studied the potential of 12 different willow clones to tolerate and accumulate $\mathrm{Cu}$ and $\mathrm{Zn}$. The study found that the investigated clones were less sensitive to $\mathrm{Cu}$ than to $\mathrm{Zn}$. However, Zn showed higher phytoextraction potential than $\mathrm{Cu}$ as it was more easily translocated to the aboveground tissues, mainly stems. The study also highlighted that the phytoremediation efficiency of the willows can be improved by selecting the most appropriate species/ clones.

Two willow species (Salix viminalis and $S$. purpurea) were studied to assess their phytostabilization potential on technosols from a former gold mining site contaminated by $\mathrm{As}, \mathrm{Sb}$ and $\mathrm{Pb}$. Both species showed tolerance to the contaminants by developing a root system and above-ground biomass. The elements were accumulated mainly in the rhizosphere. It was found that only $S$. purpurea is really efficient in vegetalization of the site and showed a strong accumulation of As. Given the biomass production and accumulation of the metalloids in the root system of $S$. purpurea, it was concluded that the species can be successfully used as a phytostabilization plant in such areas. However, when it comes to extraction, it would take thousands of years to extract all the toxic elements presented in the site [94]. Lafleur et al. [96] suggest that willows can be used to remediate groundwater contaminated with pesticides due to their ability to filter and degrade pesticides (ETU and atrazine).

Several authors [108-110] have pointed out the efficiency of phytoremediation of contaminated soil and the production of biofuels. The main reason is that the demand for biomass as an alternative energy source is increasing. SRC plantations can be established on contaminated soils of industrial zones or other sites contaminated with heavy metals and metalloids in order to combine biomass production with environmental remediation [111-113]. Phytoremediation of heavy metals and metalloids from contaminated soils and waters is considered a low-cost and environmentally friendly method of extracting pollutants from the environment $[114,79]$. Moreover, there is potential for the extraction of metals with market value [115].

SRC plantations can also be used for biological wastewater treatment by applying liquid and semi-solid sludge directly to them as fertilizers [116]. Calculations showed that the application of wastewater and sewage sludge to SRC increases profitability by decreasing fertilisation costs and increasing biomass production $[117,118]$. The use of sewage water for irrigation and application of sludge on SRC plantations thus provides both economic and environmental benefits, assuming proper management $[119,120]$. According to Rosenqvist and Dawson [118], if an SRC plantation was irrigated by wastewater in a rate of $150 \mathrm{~kg} \mathrm{ha}^{-1} \mathrm{~N}, 1$ ha would treat the waste from 120 people. Approximately 1250 ha of SRC would thus be required to treat $10 \%$ of the wastewater from Northern Ireland. Dimitriou and Rosenqvist [117] calculated that if all available sludge and wastewater were applied to SRC plantations, approximately 6000 PJ of renewable energy could be produced annually in Europe.

According to Godley et al. [121], the willow SRC can effectively reduce the environmental burden of the discharged landfill leachate by attenuating the leachate contamination. The willows would also benefit from the fertiliser value of the leachate components and thus increase the biomass yield.

There are several examples of the use of willows in large-scale phytoremediation systems. In Sweden, willow plantations were established to treat wastewater, landfill leachate and runoff water from sawmills and pulp mills [122]. A willow plantation was successfully established to treat wastewater from Linwoods milk processing and bakery operation in Ireland. The plantation was irrigated with the partially treated effluent. The irrigation system reduced costs of the effluent transportation previously transported 7 miles to the treatment facilities. The environmental benefits included recycling of all the wastewater, carbon footprint savings, as well as production of wood fuel for biomass boilers and thus decreasing the use of fossil fuels [91].

Experimental research conducted in the tailing pond of the biggest coal combusting power plant in Slovakia, Vojany, showed that willows are suitable for the phytostabilization of the pond. The willows also represent a source of biomass that can be co-incinerated in the power plant. Based on the experimental model, approximately 80 tons of wood chips could be coincinerated on a daily basis in the Vojany power plant [58].

Other studied energy plants include Arundo donax and Miscanthus spp. Based on the scientific reports, both energy plants can be used (similarly to willows and poplars) for energy purposes combined with the remediation of contaminated and marginalized soils that are not used for food production [23, 123-128].

A. donax is a very promising plant in terms of biomass production and its conversion to bioenergy and bioproducts [129-131]. It can be adapted to a broad range of environments. However, it has a high invasive potential, therefore ecological control should be addressed [129]. Miscanthus is a fast-growing grass used for bioenergy production [132] that grows relatively well on contaminated soils. The amount of contaminants transferred to the plant is low and thus the produced biomass can be used as a biofuel [123].

According to a recently published study, A. donax provides higher yields than Miscanthus $\times$ giganteus [21], mainly due to the fact that $A$. donax can be harvested multiple times per year, which is not recommended for Miscanthus. However, 
A. donax requires more energy input for planting than Miscanthus [129]. The yield of the above-ground biomass can significantly exceed the production of other plant species grown for energy purposes [133]. Genetic resources of $A$. donax were collected in Sicily and Calabria in order to evaluate the production potential of the species. The study focused on evaluating 39 clones. The average dry matter yield was $10.6 \mathrm{t} \mathrm{ha}^{-1}$ in the first year and $22.1 \mathrm{t} \mathrm{ha}^{-1}$ in the second year [134]. The results of a long-term field experiment in central Italy showed that $A$. donax had a higher annual production of the dry matter $\left(37.7 \mathrm{t} \mathrm{ha}^{-1}\right)$ than $M . \times$ giganteus $\left(28.7 \mathrm{t} \mathrm{ha}^{-1}\right)$ [135]. Del Giudice et al. [136] reported even higher dry matter production of coastal vegetation of $A$. donax in Central Italy, ranging from 43.4 to $59 \mathrm{t} \mathrm{ha}^{-1}$.

A. donax can also be used as an ecological indicator of environmental conditions [137]. The species showed potential for remediating soils contaminated with heavy metals, such as Cd [138, 139], Co, Fe [125], Ni [125-127, 140], $\mathrm{Pb}$ [23] and $\mathrm{Zn}[23,140]$. Richveisová et al. [140] confirmed the distribution of $\mathrm{Cd}$ and $\mathrm{Zn}$ in A. donax from roots to above-ground biomass, pointing to its phytoextraction potential. A. donax was able to accumulate $\mathrm{Cd}$ to a higher extent without any adverse effects on its growth. Therefore, it could be used for the treatment of $\mathrm{Cd}$-contaminated sewage and industrial wastewaters [127]. Atma et al. [126] evaluated the accumulation of $\mathrm{Ni}$ in $A$. donax. The results showed that the plant was able to survive high $\mathrm{Ni}$ content, thus indicating its potential for phytoextraction of $\mathrm{Ni}$. A.donax is also a selenium hyperaccumulator plant that is able to clean Se-contaminated agricultural soils and wastewaters [141].

A. donax can be grown on marginal sites and sites contaminated by trace elements as well as in constructed wetlands [142]. Constructed wetland systems with A. donax and Sarcocornia provide a promising solution for treating tannery wastewater [22]. Alshaal et al. [125] showed that $A$. donax can be used for decontamination of land flooded by toxic red mud from an aluminium manufacturing plant in Hungary in 2010. A. donax decreased available trace metals $(\mathrm{Cd}, \mathrm{Co}, \mathrm{Fe}, \mathrm{Ni}$ and $\mathrm{Pb}$ ) as well as salinity and $\mathrm{pH}$ of the red mud.

Similarly to A. donax, Miscanthus was also reported to be suitable for phytoremediation of heavy metals, such as $\mathrm{Cd}, \mathrm{Co}, \mathrm{Cu}, \mathrm{Fe}, \mathrm{Ni}, \mathrm{Pb}, \mathrm{Zn}[21,102,104$, 125-128, 143-145]. Miscanthus was planted on soils contaminated by the Chernobyl nuclear accident [146] and used for revitalisation of mining brownfields in Slovakia [147]. Experiments conducted in Romania on soils contaminated by $\mathrm{Pb}$ and $\mathrm{Cd}$ confirmed the high ability of biomass production of Miscanthusgiganteus. The content of $\mathrm{Pb}$ and $\mathrm{Cd}$ accumulated in the aboveground biomass was small, enabling its unlimited energy use [148].

Pidlisnyuk et al. [149] studied the use of M. giganteus on a contaminated site of a former military area in Kamenetz-Podilsky, Ukraine. The site is contaminated mainly by $\mathrm{Fe}, \mathrm{Mn}$, $\mathrm{Ti}$ and $\mathrm{Zn}$. After two growing seasons, research confirmed the allocation of the studied elements - mainly in the roots and less in the stems and leaves. The results showed that $M$. giganteus can be used both for phytoremediation and energy production. Iqbal et al. [150] stated that Miscanthus decreases the availability of $\mathrm{Cu}$ in soil. The increase of organic $\mathrm{C}$ in soil caused by the Miscanthus growth is beneficial for the absorption of $\mathrm{Cu}$ compounds that further decrease its biological availability.

$\mathrm{Li}$ et al. [151] reported the ability of energy grasses to produce biomass and also accumulate higher concentrations of $\mathrm{Zn}$ and $\mathrm{Cr}$ in their roots. The concentration of these elements was seven times higher in roots compared to the above-ground biomass. It was confirmed that Miscanthus $\times$ giganteus also tolerates high concentrations of $\mathrm{Ni}$ and is able to accumulate it [152].

Miscanthus and 16 willow species and cultivars were tested in a palladium-contaminated synthetic and minesourced tailings. The results indicated the possibility of using the plants for accumulating palladium and decreasing the overall environmental impacts associated with its extraction [153].

\section{Conclusions}

Contamination of the environment is a serious global issue. Therefore, it is necessary to implement effective and environmentally sound remediation approaches. Phytoremediation is a very promising eco-friendly and cost-effective technology that is also expected to be commercially feasible in the near future. Phytoremediation activities can also help in ecological recycling of heavy metals and metalloids. Due to the interdisciplinary nature of the phytoremediation research, knowledge from different fields of studies should be implemented for reaching the best results. Approaching the private and public sectors and providing them with education about phytoremediation activities is another important aspect. Research studies proved that energy plantations of Salix, Populus, Miscanthus and Arundo donax (as well as other species) are suitable for providing sustainable biomass yields while decreasing the negative environmental impact of polluted water, land and air. Energy plantations established on contaminated land provide environmentally and economically beneficial treatment of soil and do not compete with food production. Coupling bioenergy production with phytoremediation could thus play an important role in energy selfsufficiency and environmental remediation of polluted land. The use of bioenergy from contaminated land can, however, be restricted due to possible emissions of toxic elements accumulated in the biomass. Phytoremediation is more suitable for moderately contaminated soil. It is less effective on heavily contaminated lands than conventional soil remediation methods. Further research in genetic engineering is required in order to increase 
the phytoremediation abilities of selected plants. Although examples show that phytoremediation has beensuccessfully established in the commercial sphere, many more such projects are needed in order to promote these activities on alarge scale.

\section{Acknowledgements}

This work was supported by VEGA grant No. 1/0147/17 and FESRD grant agency project Nos. 2/2017 and $3 / 2017$.

\section{Conflict of Interest}

The authors declare no conflict of interest.

\section{References}

1. LEPP N.W., Ed. Effect of Heavy Metal Pollution on Plants. Publisher: Dordrecht, Springer Netherlands. 1981.

2. LEPP N.W., Ed. Effect of Heavy Metal Pollution on Plants: Effects of Trace Metals on Plant Function. Publisher: Springer Netherlands. 1981.

3. JÄRUP L. Hazards of heavy metal contamination. British medical bulletin, 68, 167, 2003.

4. WUANA R.A., OKIEIMEN F.E. Heavy Metals in Contaminated Soils: A Review of Sources, Chemistry, Risks and Best Available Strategies for Remediation. ISRN Ecology, 2011, 1, 2011.

5. DURUIBE O.J., OGWUEGBU C.M.O., EGWURUGWU N.J. Heavy metal pollution and human biotoxic effects. International Journal of Physical Sciences, 2 (5), 112, 2007.

6. KOVÁČIK A., ÁRVAY J., TUŠIMOVÁ E., HARANGOZO L., TVRDÁ E., ZBYŇOVSKÁ K., CUPKA P., ANDRASCIKOVA S., TOMÁŠJ., MASSÁNYI P. Seasonal variations in the blood concentration of selected heavy metals in sheep and their effects on the biochemical and hematological parameters. Chemosphere, 168, 365, 2017.

7. ÁRVAY J., DEMKOVÁ L., HAUPTVOGL M., MICHALKO M., BAJČAN D., STANOVIČ R., TOMÁŠ J., HRSTKOVÁ M., TREBICHALSKÝ P. Assessment of environmental and health risks in former polymetallic ore mining and smelting area, Slovakia: Spatial distribution and accumulation of mercury in four different ecosystems. Ecotoxicology and Environmental Safety, 144,236,2017.

8. DEMKOVÁ L., ÁRVAY J., BOBULSKÁ L., TOMÁS̆ J., STANOVIČ R., LOŠÁK T., HARANGOZO L., VOLLMANNOVÁ A., BYSTRICKÁ J., MUSILOVÁ J., JOBBÁGY J. Accumulation and environmental risk assessment of heavy metals in soil and plants of four different ecosystems in a former polymetallic ores mining and smelting area (Slovakia). Journal of Environmental Science and Health, Part A, 52 (5), 479, 2017.

9. MUSILOVÁ J., ÁRVAY J., VOLLMANNOVÁ A., TÓTH T., TOMÁŠ J. Environmental Contamination by Heavy Metals in Region with Previous Mining Activity. Bulletin of Environmental Contamination and Toxicology, 97 (4), $569,2016$.
10. VOLLMANNOVÁ A., KUJOVSKÝ M., STANOVIČ R., ÁRVAY J., HARANGOZO L. Contamination of the Alluvium of the Nitra River in Slovakia by Cadmium, Mercury and Lead as a Result of Previous Intense Industrial Activity. Bulletin of Environmental Contamination and Toxicology, 97(4), 561, 2016.

11. ALI H., KHAN E., SAJAD M. A. Phytoremediation of heavy metals - Concepts and applications. Chemosphere, 91 (7), 869, 2013.

12. DIXIT R., WASIULLAH E., MALAVIYA D., PANDIYAN K., SINGH U., SAHU A., SHUKLA R., SINGH B.P., RAI J.P., SHARMA P.K., LADE H., PAUL D. Bioremediation of Heavy Metals from Soil and Aquatic Environment: An Overview of Principles and Criteria of Fundamental Processes. Sustainability, 7 (2), 2189, 2015.

13. ÁRVAY J., STANOVIČ R., BAJČAN D., SLÁVIK M., MIŠŠÍK, J. Content of Heavy Metals in Soil and Crop from Middle Spiš Area. Journal of Microbiology Biotechnology, 2 (2), 2013.

14. SLÁVIK M., TÓTH T., HARANGOZO L', ÁRVAY J., STANOVIČ R., MIŠŠÍK J. The Content of Mercury in Edible Mushrooms From Middle Spiš. Journal of Microbiology, Biotechnology and Food Sciences, 2 (1), 2115, 2013

15. DEMKOVÁ L., BOBUL'SKÁ L., ÁRVAY J., JEZNÝ T. DUCSAY L. Biomonitoring of heavy metals contamination by mosses and lichens around Slovinky tailing pond (Slovakia). Journal of Environmental Science and Health, Part A, 52 (1), 30, 2017.

16. AGARWAL S.K. Heavy metal pollution. Publisher: A.P.H. Pub. Corp. 2009.

17. MARTIN M.H., COUGHTREY P. J. Biological Monitoring of Heavy Metal Pollution: Land and Air. Springer Science Business Media. 2012.

18. DEMKOVÁ L., BARANOVÁ B., OBOŇA J., ÁRVAY J., LOŠÁK T. Assessment of air pollution by toxic elements on petrol stations using moss and lichen bag technique. Plant, Soil and Environment, 63 (8), 2017.

19. ÁRVAY J., TOMÁŠ J., HAUPTVOGL M., KOPERNICKÁ M., KOVÁČIK A., BAJČAN D., MASSÁNYI P. Contamination of wild-grown edible mushrooms by heavy metals in a former mercury-mining area. Journal of Environmental Science and Health - Part B Pesticides, Food Contaminants, and Agricultural Wastes, 49 (11), 2014.

20. STAMENKOVIC J., GUSTIN M.S. Nonstomatal versus stomatal uptake of atmospheric mercury. Environmental Science and Technology, 43 (5), 1367, 2009.

21. BARBOSA B., BOLÉO S., SIDELLA S., COSTA J., DUARTE M.P., MENDES B., COSENTINO S.L, FERNANDO A.L. Phytoremediation of Heavy MetalContaminated Soils Using the Perennial Energy Crops Miscanthus spp. and Arundo donax L. Bioenergy Research, 8 (4), 1500, 2015.

22. CALHEIROS C.S.C., QUITÉRIO P.V.B., SILVA G., CRISPIM L.F.C., BRIX H., MOURA S.C., CASTRO P.M.L. Use of constructed wetland systems with Arundo and Sarcocornia for polishing high salinity tannery wastewater. Journal of Environmental Management, 95 (1), 66, 2012.

23. FIORENTINO N., VENTORINO V., ROCCO C., CENVINZO V., AGRELLI D., GIOIA L., DI MOLA I., ADAMO P., PEPE O., FAGNANO M. Giant reed growth and effects on soil biological fertility in assisted phytoremediation of an industrial polluted soil. Science of the Total Environment, 575, 1375, 2017. 
24. GERHARDT K.E., GERWING P.D., GREENBERG B.M. Opinion: Taking phytoremediation from proven technology to accepted practice. Plant Science, 256, 170,2017.

25. LUO J., QI S., GU X.W.S., WANG J., XIE X. Evaluation of the phytoremediation effect and environmental risk in remediation processes under different cultivation systems. Journal of Cleaner Production, 119, 25, 2015.

26. MAHAR A., WANG P., ALI A., AWASTHI M.K., LAHORI A.H., WANG Q., LI R., ZHANG Z. Challenges and opportunities in the phytoremediation of heavy metals contaminated soils: A review. Ecotoxicology and Environmental Safety, 126, 111, 2016.

27. PANDEY V.C., BAJPAI O., SINGH N. Energy crops in sustainable phytoremediation. Renewable and Sustainable Energy Reviews, 54, 58, 2016.

28. TARIQ S.R., ASHRAF A. Comparative evaluation of phytoremediation of metal contaminated soil of firing range by four different plant species. Arabian Journal of Chemistry, 9 (6), 806, 2016

29. ZIARATI P., ZIARATI N.N., NAZERI S., SABERGERMI M. Phytoextraction of Heavy Metals by two Sorghum Spices in Treated Soil "Using Black Tea Residue for Cleaning-Uo the Contaminated Soil." Oriental Journal of Chemistry, 31 (1), 317, 2015.

30. MLECZEK M., GOLIŃSKI P., KRZESŁOWSKA M., GĄSECKA M., MAGDZIAK Z., RUTKOWSKI P., BUDZYŃSKA S., WALISZEWSKA B., KOZUBIK T., KAROLEWSKI Z., NIEDZIELSKI P. Phytoextraction of potentially toxic elements by six tree species growing on hazardous mining sludge. Environmental science and pollution research international, 24 (28), 22183, 2017.

31. MOSA K. A., SAADOUN I., KUMAR K., HELMY M., DHANKHER O. P. Potential Biotechnological Strategies for the Cleanup of Heavy Metals and Metalloids. Frontiers in Plant Science, 7, 1, 2016

32. TOMÁŠ J., ÁRVAY J., TÓTH T. Heavy metals in productive parts of agricultural plants. Journal of Microbiology Biotechnology, (1), 819, 2012.

33. OSMAN K.T. Soil Degradation, Conservation and Remediation. Publisher: Springer Netherlands. 2014.

34. PAZ-ALBERTO A.M., SIGUA G.C. Phytoremediation: A Green Technology to Remove Environmental Pollutants. American Journal of Climate Change, 2 (1), 71, 2013.

35. SIMS R.E.H., HASTINGS A., SCHLAMADINGER B., TAYLOR G., SMITH P. Energy crops: current status and future prospects. Global Change Biology, 12 (11), 2054, 2006.

36. HALFORD N.G., KARP A. Energy crops. Royal Society of Chemistry. 2010.

37. RUI J., TONG-TONG W., JIN S., SHENG G., WEI Z., YA-JUN Y., SHAO-LINC., RYUSUKE H. Modeling the biomass of energy crops: Descriptions, strengths and prospective. Journal of Integrative Agriculture, 16 (166), 1197, 2017.

38. DEMO M., FAZEKAS A., HAUPTVOGL M., SKLADAN B., TÓTHOVÁ M. Produkčný a energetický potenciál švédskych odrôd rýchlorastúcej dreviny rodu Salix pestovanej v suchších pôdno-klimatických podmienkach juhozápadného Slovenska. Nitra: Slovak University of Agriculture in Nitra. 2011 [In Slovak].

39. DEMO M., BAKO A., HÚSKA D., HAUPTVOGL M. Biomass production potential of different willow varieties (Salix spp.) grown in soil-climatic conditions of southwestern Slovakia. Wood Research, 58 (4), 2013.

40. JUREKOVÁ Z., KOTRLA M., PAUKOVÁ, Ž. Life Cycle of Miscanthus $\times$ Giganteus (Greef Et Deu) Grown in
Southwestern Slovakia Conditions. Acta Regionalia et Environmentalica, 10 (2), 38, 2013.

41. JUREKOVÁ Z., HÚSKA D., KOTRLA M., PRČÍK M., HAUPTVOGL M. Comparison of energy sources grown on agricultural land. Acta Regionalia et Environmentalica, $12(2), 38,2015$.

42. PRČIK M., KOTRLA M. Different planting material for establishment of the Miscanthus energy grass plantation. Journal of Central European Agriculture, 17 (3), 778, 2016.

43. HAUPTVOGL M. Increase of biomass production of fastgrowing willows in the first year of the second harvest cycle. Acta Regionalia et Environmentalica, 10 (2), 34, 2013.

44. JUREKOVÁ Z., DRAŽIČ G., KOTRLA M., MARIŠOVÁ E., MILOVANOVIČ J., TÓTHOVÁ M., KONČEKOVÁ L. Biological factors influencing the growth and biomass production of willows planted in Southern Slovakia. Acta Regionalia et Environmentalica, 8 (2), 47, 2011.

45. JUREKOVÁ Z., KOTRLA M., PAUKOVÁ Ž., PRČÍK, M. The growth and yield of different Miscanthus genotypes in the conditions of South-Western Slovakia. Acta Regionalia et Environmentalica, 9 (2), 29, 2012.

46. KOTRLA M., PRČÍK M. Growth dynamics of perennial energy grass genus Miscanthus studied in Slovakia. In SGEM. Sofia: STEP92 Technology. 2014.

47. DOBSON A.P., BRADSHAW A.D., BAKER A.J.M. Hopes for the Future: Restoration Ecology and Conservation Biology. Science, 277 (5325), 515, 1997.

48. PAULSON M., BARDOS P., HARMSEN J., WILCZEK J., BARTON M., EDWARDS D. The practical use of short rotation coppice in land restoration. Land Contamination Reclamation, 11 (3), 323, 2003.

49. MLECZEK M., RISSMANN I., RUTKOWSKI P., KACZMAREK Z., GOLINSKI P. Accumulation of selected heavy metals by different genotypes of Salix. Environmental and Experimental Botany, 66 (2), 289, 2009.

50. JAISHANKARM., TSETEN T., ANBALAGAN N., MATHEW B.B., BEEREGOWDA K.N. Toxicity, mechanism and health effects of some heavy metals. Interdisciplinary Toxicology, 7 (2), 60, 2014.

51. SINGOVSZKA E., BALINTOVA M., DEMCAK S., PAVLIKOVA P. Metal Pollution Indices of Bottom Sediment and Surface Water Affected by Acid Mine Drainage. Metals, 7 (8), 284, 2017.

52. SARWAR N., IMRAN M., SHAHEEN M.R., ISHAQUE W., KAMRAN M.A., MATLOOB A., REHIM A., HUSSAIN S. Phytoremediation strategies for soils contaminated with heavy metals: Modifications and future perspectives. Chemosphere, 171, 710,2017.

53. WILCKE W., KRAUSS M., KOBZA J. Concentrations and forms of heavy metals in Slovak soils. Journal of Plant Nutrition and Soil Science, 168 (5), 676, 2005.

54. KLINDA J., MIČÍK T., NÉMETHOVÁ M., SLÁMKOVÁ, M. Environmental regionalization of the Slovak Republic. Bratislava, Banská Bystrica. 2016.

55. LIESKOVSKÁ Z., NÉMETHOVÁ M. Správa o stave životného prostredia Slovenskej republiky v roku 2015. 2016 [In Slovak].

56. TOMÁŠ J., ÁRVAY J., HARANGOZO L., SLÁVIK M., MIŠŠÍK J., STANOVIČ R. The level of plant contamination by mercury from the Rudñany mines immision area. Journal of Microbiology Biotechnology, 2 (1), 2013.

57. SLOVAK ENVIRONMENT AGENCY. Public Information system of contaminated sites. 2017. 
58. BOSÁK M. Biomass Production on Reclaimed Areas Tailing Ponds. In Biomass Volume Estimation and Valorization for Energy. InTech. 2017.

59. MASAROVIČOVÁ M., SLÁVIK I.Komplexný monitoring odkalísk SR (čast' 10). Bratislava. 2014 [In Slovak].

60. ANGELOVIČOVÁ L., FAZEKAŠOVÁ D. Contamination of the Soil and Water Environment by Heavy Metals in the Former Mining Area of Rudňany (Slovakia). Soil Water Res, 9 (1), 18,2014.

61. FERNÁNDEZ S., POSCHENRIEDER C., MARCENÒ C., GALLEGO J.R., JIMÉNEZ-GÁMEZ D., BUENO A., AFIF E. Phytoremediation capability of native plant species living on $\mathrm{Pb}-\mathrm{Zn}$ and $\mathrm{Hg}-\mathrm{As}$ mining wastes in the Cantabrian range, north of Spain. Journal of Geochemical Exploration, 174, 10, 2017.

62. BUDZYŃSKA S., KRZESŁOWSKA M., NIEDZIELSKI P., GOLIŃSKI P., MLECZEK M. Arsenite phytoextraction and its influence on selected nutritional elements in oneyear-old tree species. Microchemical Journal, 133, 530, 2017.

63. MAXIM A., STOIE A., ȘANDOR M., ODAGIU A., PERȚEA V., MIHALESCU L. The Natural Rehabilitation of Tailing Ponds from Căpuș, Cluj. Bulletin USAMV series Agriculture, 72 (1), 1843, 2015.

64. FAVAS P.J., PRATAS J., VARUN M., D'SOUZA R., PAUL M.S. Phytoremediation of Soils Contaminated with Metals and Metalloids at Mining Areas: Potential of Native Flora. In Environmental Risk Assessment of Soil Contamination, HERNANDEZ-SORIANO M.C., Ed., In Tech. 2014.

65. NIROLA R., MEGHARAJ M., PALANISAMI T., ARYAL R., VENKATESWARLU K., NAIDU R.Evaluation of metal uptake factors of native trees colonizing an abandoned copper mine - a quest for phytostabilization. Journal of Sustainable Mining, 14 (3), 115, 2015.

66. VARGA C., MARIAN M., MIHALY-COZMUTA L., MIHALY-COZMUTA A., MIHALESCU L. Evaluation of the Phytoremediation Potential of the SalixCaprea in Tailing Ponds. Analele Universitatii din Oradea: Fascicula Biologie, 16 (1), 141. 2009.

67. PANDEY V.C., PANDEY D.N., SINGH N. Sustainable phytoremediation based on naturally colonizing and economically valuable plants. Journal of Cleaner Production, 86, 37, 2015.

68. GHOSH M., SINGH S.P. A review on phytoremediation of heavy metals and utilization of its by products. Applied Ecology and Environmental Research, 6 (4), 214, 2005.

69. PADMAVATHIAMMA P.K., LI L.Y. Phytoremediation technology: Hyper-accumulation metals in plants. Water, Air, and Soil Pollution, 184 (1-4), 105, 2007.

70. SALT D.E., BLAYLOCK M., KUMAR N.P., DUSHENKOV V., ENSLEY B.D., CHET I., RASKIN I. Phytoremediation: a novel strategy for the removal of toxic metals from the environment using plants. Biotechnology, 13 (5), 468, 1995.

71. SUSARLA S., MEDINA V.F., MCCUTCHEON S.C. Phytoremediation: An ecological solution to organic chemical contamination. Ecological Engineering, 18 (5), 647, 2002.

72. ROHRBACHER F., ST-ARNAUD M. Root Exudation: The Ecological Driver of Hydrocarbon Rhizoremediation. Agronomy, 6 (1), 19, 2016.

73. MONTPETIT É., LACHAPELLE E. New environmental technology uptake and bias toward the status quo: The case of phytoremediation. Environmental Technology and Innovation, 7, 102, 2017.

74. WAN X., LEI M., CHEN T. Cost-benefit calculation of phytoremediation technology for heavy-metalcontaminated soil. Science of the Total Environment, 563564, 796, 2016.

75. BURGES A., EPELDE L., BLANCO F., BECERRIL J.M., GARBISU C. Ecosystem services and plant physiological status during endophyte-assisted phytoremediation of metal contaminated soil. Science of the Total Environment, 584-585, 329, 2017.

76. FENG N.X., YU J., ZHAO H.M., CHENG Y.T., MO C.H., CAI Q.Y., LI Y.W., LI H., WONG M.H. Efficient phytoremediation of organic contaminants in soils using plant-endophyte partnerships. Science of the Total Environment, 583, 352, 2017.

77. HYBSKÁ H. Základy ekotoxikológie. Publisher: Zvolen: TU Zvolen. 2015 [In Slovak].

78. RUNGWA S., ARPA G., SAKULAS H., HARAKUWE A., TIMI D. Phytoremediation - An Eco-friendly and Sustainable Method of Heavy Metal Removal from Closed Mine Environments in Papua New Guinea. Procedia Earth and Planetary Science, 6, 269, 2013.

79. TANGAHU B.V., SHEIKH ABDULLAH S.R., BASRI H., IDRIS M., ANUAR N., MUKHLISIN M. A review on heavy metals $(\mathrm{As}, \mathrm{Pb}$, and $\mathrm{Hg})$ uptake by plants through phytoremediation. International Journal of Chemical Engineering, 2011, 2011.

80. GOMES H.I. Phytoremediation for bioenergy : challenges and opportunities. Environmental Technology Reviews, 1 (1), 59, 2012.

81. TRIPATHI V., EDRISI S.A., ABHILASH P. C. Towards the coupling of phytoremediation with bioenergy production. Renewable and Sustainable Energy Reviews, 57, 1386, 2016.

82. FIORESE G., GUARISO G. A GIS-based approach to evaluate biomass potential from energy crops at regional scale. Environmental Modelling and Software, 25 (6), 702, 2010.

83. CITTERIO S., SANTAGOSTINO A., FUMAGALLI P., PRATO N., RANALLI P., SGORBATI S. Heavy metal tolerance and accumulation of $\mathrm{Cd}, \mathrm{Cr}$ and $\mathrm{Ni}$ by Cannabis sativa L. Plant and Soil, 256, 243, 2003.

84. MURAKAMI M., AE N. Potential for phytoextraction of copper, lead, and zinc by rice (Oryza sativa L.), soybean (Glycine max [L.] Merr.), and maize (Zea mays L.). Journal of Hazardous Materials, 162 (2-3), 1185, 2009.

85. POPP J., LAKNER Z., HARANGI-RÁKOS M., FÁRI $M$. The effect of bioenergy expansion: Food, energy, and environment. Renewable and Sustainable Energy Reviews, 32, 559, 2014.

86. GINNEKEN L.V. MEERS E., GUISSON R., RUTTENS A., ELST K., TACK F.M.G., VANGRONSVELD J., DIELS L., DEJONGHE W. Phytoremediation for heavy metalcontaminated soils combined with bioenergy production. Journal of Environmental Engineering and Landscape Management, 15 (4), 227, 2007.

87. LIPHADZI M.S., KIRKHAM M.B. Phytoremediation of soil contaminated with heavy metals: a technology for rehabilitation of the environment. South African Journal of Botany, 71 (1), 24, 2005.

88. BITTSÁNSZKY A., GYULAI G., GULLNE G., KISS J., SZABÓ Z., KÁTAY G., HESZKY L., KÖMÍVES T. In vitro breeding of grey poplar (Populus $\times$ canescens) for phytoremediation purposes. Journal of Chemical Technology Biotechnology, 84 (6), 890, 2009.

89. GYULAI G., BITTSÁNSZKY A., SZABÓ Z., WATERS L., GULLNER G., KAMPFL G., HELTAI G., KÖMÍVES, T. Phytoextraction Potential of Wild Type 
and 35S-GSH I Transgenic Poplar Trees (Populus $\times$ Canescens) for Environmental Pollutants Herbicide Paraquat, Salt Sodium, Zinc Sulfate and Nitric Oxide In Vitro. International Journal of Phytoremediation, 16 (4), 379, 2014

90. ARONSSON P.R., DAHLIN T., DIMITRIOU I. Treatment of landfill leachate by irrigation of willow coppice - Plant response and treatment efficiency. Environmental Pollution, 158, 795, 2010.

91. MCCRACKEN A., BLACK A., CAIRNS P., DUDDY A.-M., GALBALLY P., FINNAN J., JOHNSTON C., MCLAUGHLIN C., MOSS B., MULLIGANO., WALSH L. Use of Short Rotation Coppice (SRC) willow for the bioremediation of effluents and leachates: Project Report. 2014.

92. PAJEVIĆ S., BORIŠEV M., NIKOLIĆ N., ARSENOV D.D., ORLOVIĆ S., ŽUPUNSKI M. Phytoextraction of heavy metals by fast-growing trees: A review. In Phytoremediation: Management of Environmental Contaminants, ANSARI A.A., GILL S.S., GILL R., LANZA G.R., NEWMANL., Eds., Publisher: Cham,Springer, Volume 3, 64, 2016.

93. ALGREEN M., TRAPP S., REIN A. Phytoscreening and phytoextraction of heavy metals at Danish polluted sites using willow and poplar trees. Environmental Science and Pollution Research, 21 (15), 8992, 2014.

94. SYLVAIN B., MIKAEL M.H., FLORIE M., EMMANUEL J., MARILYNE S., SYLVAIN B., DOMENICO M. Phytostabilization of As, $\mathrm{Sb}$ and $\mathrm{Pb}$ by two willow species ( $S$. viminalis and $S$. purpurea) on former mine technosols. Catena, 136, 44, 2016.

95. PULFORD I.D., WATSON C. Phytoremediation of heavy metal-contaminated land by trees - a review. Environment International, 29 (4), 529, 2003.

96. LAFLEUR B., SAUVÉ S., DUY S.V., LABRECQUE M. Phytoremediation of groundwater contaminated with pesticides using short-rotation willow crops: A case study of an apple orchard. International Journal of Phytoremediation, 18 (11), 1128, 2016.

97. WANG J., FENG X., ANDERSON C.W.N., XING Y., SHANG L. Remediation of mercury contaminated sites - A review. Journal of Hazardous Materials, 221-222, 1, 2012.

98. VANDECASTEELE B., MEERS E., VERVAEKE P., VOS B. DE, QUATAERT P., TACK F.M.G. Growth and trace metal accumulation of two Salix clones on sediment-derived soils with increasing contamination levels. Chemosphere, 58 (8), 995, 2005.

99. KERSTEN G., MAJESTIC B., QUIGLEY M. Phytoremediation of cadmium and lead-polluted watersheds. Ecotoxicology and Environmental Safety, 137, 225, 2017.

100. DRZEWIECKA K., MLECZEK M., GĄSECKA M., MAGDZIAK Z., GOLIŃSKI P., CHADZINIKOLAU T. Copper phytoextraction with Salix purpurea $\times$ viminalis under various $\mathrm{Ca} / \mathrm{Mg}$ ratios. Part 2. Effect on organic acid, phenolics and salicylic acid contents. Acta Physiologiae Plantarum, 36 (4), 903, 2014.

101. GOMMERS A., GAVERT T., SMOLDERS E., MERCKX R., VANDENHOVE H. Radiocaesium soil-to-wood transfer in commercial willow short rotation coppice on contaminated farm land. Journal of Environmental Radioactivity, 78, 267, 2005.

102. SALAM M.M.A., KAIPIAINEN E., MOHSIN M., VILLA A., KUITTINEN S., PULKKINEN P.,PELKONEN P., MEHTÄTALO L.,PAPPINEN A.
Effects of contaminated soil on the growth performance of young Salix (Salix schwerinii E.L. Wolf) and the potential for phytoremediation of heavy metals. Journal of Environmental Management, 183, 467, 2016.

103. TANG C., SONG J., HU X., HU X., ZHAO Y., LI B., DANLING O., PENG L. Exogenous spermidine enhanced $\mathrm{Pb}$ tolerance in Salix matsudana by promoting $\mathrm{Pb}$ accumulation in roots and spermidine, nitric oxide, and antioxidant system levels in leaves. Ecological Engineering, 107, 41, 2017.

104. KACÁLKOVÁ L., TLUSTOŠ P., SZÁKOVÁ J. Phytoextraction of Risk Elements by Willow and Poplar Trees. International Journal of Phytoremediation, 17 (5), 414, 2015.

105. KUBÁTOVÁ P., HEJCMAN M., SZÁKOVÁ J., VONDRÁČKOVÁ S., TLUSTOŠ P. Effects of Sewage Sludge Application on Biomass Production and Concentrations of $\mathrm{Cd}, \mathrm{Pb}$ and $\mathrm{Zn}$ in Shoots of Salix and Populus Clones: Improvement of Phytoremediation Efficiency in Contaminated Soils. Bioenergy Research, 9 (3), 809, 2016

106. RADOJČIĆ REDOVNIKOVIĆ I., DE MARCO A., PROIETTI C., HANOUSEK K., SEDAK M., BILANDŽIĆ N., JAKOVLJEVIĆ T. Poplar response to cadmium and lead soil contamination. Ecotoxicology and Environmental Safety, 144, 482, 2017.

107. YANG W., WANG Y., ZHAO F., DING Z., ZHANG X., ZHU Z., YANG X. Variation in copper and zinc tolerance and accumulation in 12 willow clones: implications for phytoextraction. Journal of Zhejiang UniversitySCIENCE B, 15 (9), 788, 2014.

108. WITTERS N., VAN SLYCKEN S., RUTTENS A., ADRIAENSEN K., MEERS E., MEIRESONNE L., TACK F.M.G., THEWYS T., LAESE., VANGRONSVELD J. Short-rotation coppice of willow for phytoremediation of a metal-contaminated agricultural area: A sustainability assessment. Bioenergy Research, 2 (3), 144, 2009.

109. KOCON A., MATYKA M. Phytoextractive potential of Miscanthus giganteus and Sida hermaphrodita growing under moderate pollution of soil with $\mathrm{Zn}$ and $\mathrm{Pb}$. Journal of Food, Agriculture and Environment, 10 (2), 1253, 2012.

110. TECHER D., MARTINEZ-CHOIS C., LAVAL-GILLY P., HENRY S., BENNASROUNE A., D'INNOCENZO M., FALLA J. Assessment of Miscanthus $\times$ giganteus for rhizoremediation of long term PAH contaminated soils. Applied Soil Ecology, 62, 42, 2012.

111. MLECZEK M., RUTKOWSKI P., RISSMANN I., KACZMAREK Z., GOLINSKI P., SZENTNER K., STRAŻYŃSKA K., STACHOWIAK A. Biomass productivity and phytoremediation potential of Salix alba and Salix viminalis. Biomass and Bioenergy, 34 (9), 1410, 2010.

112. ABHILASH P.C., POWELL J.R., SINGH H.B., SINGH B.K. Plant-microbe interactions: novel applications for exploitation in multipurpose remediation technologies. Trends in Biotechnology, 30, 416. 2012.

113. ŠYC M., POHOŘELÝ M., KAMENÍKOVÁ P., HABART J., SVOBODA K., PUNČOCHÁŘ M. Willow trees from heavy metals phytoextraction as energy crops. Biomass and Bioenergy, 37, 106, 2012.

114. SHEORAN V., SHEORAN A.S., POONIA P. Phytoremediation of metal contaminated mining sites. International Journal of Earth Sciences and Engineering, 5 (3), 428, 2012. 
115. VANGRONSVELD J., HERZIG R., WEYENS N., BOULET J., ADRIAENSEN K., RUTTENS A., THEWYS T., VASSILEV A., MEERS E., NEHNEVAJOVA E., VAN DER LELIE D., MENCH M. Phytoremediation of contaminated soils and groundwater: Lessons from the field. Environmental Science and Pollution Research, 16 (7), 765, 2009.

116. CASLIN B., FINNAN J., MCCRACKEN A. Short rotation coppice willow: Best practice guidelines. 2010.

117. DIMITRIOU I., ROSENQVIST H. Sewage sludge and wastewater fertilisation of Short Rotation Coppice (SRC) for increased bioenergy production - Biological and economic potential. Biomass and Bioenergy, 35, 835, 2011.

118. ROSENQVIST H., DAWSON M. Economics of willow growing in Northern Ireland. Biomass and Bioenergy, 28 (1), 7, 2005.

119. HASSELGREN K. Use and treatment of municipal waste products in willow biomass plantations. Water Resources Engineering, Lund University. 2003.

120. DIMITRIOU I. Safe reuse of municipal wastewater and sewage sludge for irrigation and fertilization. In Short Rotation Plantations: Guidelines for efficient biomass production with the safe application of wastewater and sewage sludge HEINSOOK., DIMITRIOUI., FOELLNERS., BUERGOW G., Eds., Publisher: International Ecological Engineering Society, pp. 159, 2008

121. GODLEY A., ALKER G., HALLETT J., MARSHALL R., RIDDELL-BLACK D. Landfill leachate nutrient recovery by willow short rotation coppice I. Yield, tissue composition and wood quality. Arboricultural Journal, 27 (4), 281, 2004

122. DIMITRIOU I., ARONSSON P. Willows for energy and phytoremediation in Sweden. Unasylva, 56 (221), 47, 2005.

123. PIDLISNYUK V., STEFANOVSKA T., LEWIS E. E., ERICKSON L.E., DAVIS L.C. Miscanthus as a Productive Biofuel Crop for Phytoremediation. Critical Reviews in Plant Sciences, 33 (1), 1, 2014.

124. JEŻOWSKI S., MOS M., BUCKBY S., CERAZYWALISZEWSKA J., OWCZARZAK W., MOCEK A., KACZMAREK Z., MCCALMONT J.P. Establishment, growth, and yield potential of the perennial grass Miscanthus $\times$ Giganteus on degraded coal mine soils. Frontiers in Plant Science, 8, 1, 2017.

125. ALSHAAL T., DOMOKOS-SZABOLCSY É., MÁRTON L., CZAKÓ M., KÁTAI J., BALOGH P., ELHAWATHN., EL-RAMADYH., FÁRI M. Phytoremediation of bauxitederived red mud by giant reed. Environmental Chemistry Letters, 11 (3), 295, 2013.

126. ATMA W., LAROUCI M., MEDDAH B., BENABDELI K., SONNET P. Evaluation of the phytoremediation potential of Arundodonax L. for nickel-contaminated soil. International Journal of Phytoremediation, 19 (4), 377, 2017.

127. KHANKHANE P.J., TABASSUM A., PATEL A. Cadmium tolerance and its enhanced accumulation potential of Arundo donax by EDTA. Journal of Environmental Biology, 38 (2), 327, 2017.

128. KRON I., PORVAZ P., TÓTH Š., KRÁLOVÁHRICINDOVÁ A., POLÁK M. Chemická analýza energetických rastlín (Miscanthus $\times$ giganteus, Sida hermaphrodita, Arundo donax) na výt’ažnost' bioetanolu. Naše Pole, (6), 46. 2016 [In Slovak].
129. GE X., XU F., VASCO-CO REA J., LI Y. Giant reed: A competitive energy crop in comparison with miscanthus. Renewable and Sustainable Energy Reviews, 54, 350.2016 .

130. LEMONS E SILVA C.F., SCHIRMER M.A., MAEDA R.N., BARCELOS C.A., PEREIRA N. Potential of giant reed (Arundo donax L.) for second generation ethanol production. Electronic Journal of Biotechnology, 18 (1), $10,2015$.

131. POPP J., HARANGI-RÁKOS M., GABNAI Z., BALOGH P., ANTAL G., BAI A. Biofuels and their co-products as livestock feed: Global economic and environmental implications. Molecules, 21 (3), 1, 2016.

132. WITZEL C.P., FINGER R. Economic evaluation of Miscanthus production - A review. Renewable and Sustainable Energy Reviews, 53, 681, 2016.

133. GUBIŠOVÁ M. Množenie Arundo donax v in vitro kultúre. Piešt’any, 2016 [In Slovak].

134. COSENTINO S.L., COPANI V., D 'AGOSTA M., SANZONE E., MANTINEO M. First results on evaluation of Arundo donax L. clones collected in Southern Italy. Industrial Crops and Products, 23 (23), 212, 2006.

135. ANGELINI L.G., CECCARINI L., DI NASSO N.N. O, BONARI E. Comparison of Arundo donax L. and Miscanthus x giganteus in a long-term field experiment in Central Italy: Analysis of productive characteristics and energy balance. Biomass and Bioenergy, 33 (4), 635, 2009.

136. DEL GIUDICE A., ASSIRELLI A., GALLUCCI F., BELLACIMA R., PARI L., SANTANGELO E. Production of energy feedstock from the riparian vegetation of Arundo donax (L.): Suitability of the chopping systems. Ecological Engineering, 102, 459, 2017.

137. BONANNO G. Arundo donax as a potential biomonitor of trace element contamination in water and sediment. Ecotoxicology and Environmental Safety, 80, 20, 2012.

138. PAPAZOGLOU E. G.Arundo donax L. stress tolerance under irrigation with heavy metal aqueous solutions. Desalination, 211 (1-3), 304, 2007.

139. SARATHAMBAL C., KHANKHANE P.J., GHARDE Y., KUMAR B., VARUN M., ARUN S. The effect of plant growth-promoting rhizobacteria on the growth, physiology, and $\mathrm{Cd}$ uptake of Arundo donax L. International Journal of Phytoremediation, 19 (4), 360, 2017.

140. RICHVEISOVÁ B.M., DÜREŠOVÁ Z., HORNÍK M., AUGUSTÍN J., PIPÍŠKA, M. Distribution of Zinc and Cadmium in Tissues of Giant Reed (Arundo Donax L.): Sequential Extraction - Radiometric Study. Nova Biotechnologica et Chimica, 13 (1), 38, 2014.

141. EL-RAMADY H.R., ABDALLA N., ALSHAAL T., ELHENAWY A.S., SHAMS M.S., FAIZY S.E.D.A., BELALE-S B., SAID A.S., RAGAB M.I., AMER M.M., FÁRI M., SZTRIK A., PROKISCH J., SELMAR D., SCHNUG E., PILON-SMITS E.A.H., EL-MARSAFAWY S.M., DOMOKOS-SZABOLCSY E. Giant reed for selenium phytoremediation under changing climate. Environmental Chemistry Letters, 13, 359,2015

142. NSANGANWIMANA F., MARCHAND L., DOUAY F., MENCH M. Arundo donax L., a Candidate for Phytomanaging Water and Soils Contaminated by Trace Elements and Producing Plant-Based Feedstock. 
A Review. International Journal of Phytoremediation, 16 (10), 982, 2014.

143. HAN Z., HU Z. Tolerance of Arundo donax to heavy metals. Ying yong sheng tai xue bao $=$ The journal of applied ecology, 16 (1), 161, 2005.

144. OUSTRIERE N., MARCHAND L., ROULET E., MENCH M. Rhizofiltration of a Bordeaux mixture effluent in pilot-scale constructed wetland using Arundo donax L. coupled with potential $\mathrm{Cu}$-ecocatalyst production. Ecological Engineering, 105, 296, 2017.

145. OUSTRIERE N., MARCHAND L., LOTTIER N., MOTELICA M., MENCH M. Long-term $\mathrm{Cu}$ stabilization and biomass yields of Giant reed and poplar after adding a biochar, alone or with iron grit, into a contaminated soil from a wood preservation site. Science of the Total Environment, 579, 620, 2017.

146. LOS L.V., ZINCHENKO L.V., ZAJVORONOVSKYI V.P. Growing and Gasification of Biofuels as Effective Direction National, for Solving Energetic and Ecological Problems: Case of Miscanthus x gigantheus. Release of Zhytomir National Agroecological University, (29), 46, 2011.

147. HROMÁDKO L., VRANOVÁ V., TECHER D., LAVALGILLY R., REJŠEK K., FORMÁNEK P., FALLA J. Composition of root exudates of Miscanthus x Giganteus Greef et Deu. Acta Universitatis Agriculturae et Silviculturae Mendelianae Brunensis, 58 (1), 71, 2010.

148. BARBU C.H., PAVEL P.B., SAND C., POP M.R. Reduced uptake of $\mathrm{Cd}$ and $\mathrm{Pb}$ by Miscanthussinensis $\times$ giganteus cultivated on polluted soil and its use as biofuel. Environmental Engineering and Management Journal, 12 (2), 1535, 2013.

149. PIDLISNYUK V., TRÖGL J., STEFANOVSKA T., SHAPOVAL P., ERICKSON, L. Preliminary Results on Growing Second Generation Biofuel Crop Miscanthus $\times$ Giganteus at The Polluted Military Site in Ukraine. Nova Biotechnologica et Chimica, 15 (1), 77, 2016.

150. IQBAL M., BERMOND A., LAMY I. Impact of miscanthus cultivation on trace metal availability in contaminated agricultural soils: Complementary insights from kinetic extraction and physical fractionation. Chemosphere, 91 (3), 287, 2013.

151. LI C., XIAO B., WANG Q. H., YAO S. H., WU J. Y. Phytoremediation of $\mathrm{Zn}$ - and $\mathrm{Cr}$-contaminated soil using two promising energy grasses. Water, Air, and Soil Pollution, 225 (7), 2014.

152. BOSIACKI M. Influence of increasing nickel content in soil on Miscanthus $\times$ giganteus Greef and Deu. Yielding and on the content of nickel in above-ground biomass. Archives of Environmental Protection, 41 (1), 72, 2015.

153. HARUMAIN Z.A.S., PARKER H.L., MUÑOZ GARCÍA A., AUSTIN M.J., MCELROY C.R., HUNT A.J., CLARK J.H., MEECH J.A., ANDERSON C.W., CIACCI L., GRAEDEL T.E., BRUCE N.C., RYLOTT E.L. Towards Financially Viable Phytoextraction and Production of Plant-Based Palladium Catalysts. Environmental Science and Technology, 51 (5), 2992, 2017. 